PLEASE NOTE! THIS IS SELF-ARCHIVED VERSION OF THE ORIGINAL ARTICLE

To cite this Article: A. Eskelinen, C. Saarikivi (2017) THE STUDENTS' LEARNING EXPERIENCES IN A MULTIPROFESSIONAL LIVING LAB, EDULEARN17 Proceedings, pp. 8354-8357.

URL: https://library.iated.org/view/ESKELINEN2017STU

doi: $10.21125 /$ edulearn.2017.0055 


\title{
THE STUDENTS' LEARNING EXPERIENCES IN A MULTIPROFESSIONAL LIVING LAB
}

\author{
A. Eskelinen, C. Saarikivi \\ Laurea University of Applied Sciences (FINLAND)
}

\begin{abstract}
The purpose of this study was to explore the Bachelor Degree Programmes of Nursing and Social Services students' learning experiences in a multiprofessional Living Lab. The aim was to offer for the students an experience to work with the mental health rehabilitees as a part of their studies in a Living Lab environment, which is a user-centered open innovation ecosystem integrating research and innovation in real life communities and settings. The Mental Health Living Lab setting was offered by Laurea University of Applied Sciences and the association of Keski-Uudenmaan Sopimuskoti Ry.

The data was collected in a feedback survey. The survey consisted of both qualitative and quantitative questions. The quantitative data was processed using SPSS Statistics and open questions were categorized.

Multiprofessional learning supported the students' abilities in the fields of nursing and social services. The students got new experiences, knowledge and more capacity to work with professionals from other fields. The students also appreciated the opportunity to work with mental health rehabilitees and they got more confidence to meet and interact with the rehabilitees. It was important to hear about the experiences of rehabilitees to gain more professional skills to collaborate with clients in the future. The benefits of multiprofessional learning were wide-ranging and the students hoped to get more opportunities to work with multiprofessional projects during their studies.
\end{abstract}

Keywords: multiprofessional, learning, experiences, living lab, nursing, social services.

\section{INTRODUCTION}

Multiprofessional working contains elements of co-operation, problem solving, activity planning and decision making with other professions. In social and health care multi-professional working is seen as an important part of client-centered work as the collaboration combines different professional knowledge and abilities together and enables them to be used in clients' care. [1] Client-centered work saves costs and it improves the effectiveness of social and health services [2]. In multi-professional teams, colleagues learn from each other by sharing information and reflecting on it together. Recognition is an important part of working in multi-professional teams. [3], [4]

Changes and competence needed in health care challenge students to learn and achieve sufficient professional and metacognitive skills during their studies. Multi-professional learning challenges students to work with each other and share their learning experiences. In this Living lab project Nursing and Social Services students worked with mental health rehabilitees as a part of their studies in a Living lab environment. In this project rehabilitees were seen as experts of their rehabilitation. Multi-professional cooperation is needed in a Living Lab environment where all participants work with jointly agreed development targets [5].

Living Lab is a user-driven open research and innovation concept, which is particularly suitable for development of new activities [5]. Laurea University of Applied Sciences and an association KeskiUudenmaan Sopimuskoti ry started the Mental Health Living Lab co-operation in spring 2015. Laurea University of Applied Sciences has been a key actor in developing Living Lab environments in Finland and more widely in Europe. Keski-Uudenmaan Sopimuskoti ry provides mental health services for rehabilitees. The main activities are day and work activities, housing services and family work. The services consist of professionally provided versatile services that include coping at home, living, rehabilitation, employment and leisure activities.

\section{MULTI-PROFESSIONAL LEARNING IN A LIVING LAB ENVIRONMENT}

A Living Lab environment is a real-life, user- centered and user-driven open innovation ecosystem integrating research and innovation. Living Labs can be defined as both an environment and an 
approach-like methodology or innovation approach. Living Lab environment examples include research, corporate, organizational, intermediary or time limited Living Labs. There are five main principles that should permeate all operations. They are value, influence, sustainability, openness and realism. [5]

Users, providers, utilizers and enablers are the actors in living labs. In the innovation process partners can be companies, users, public organisations and researchers. Users have a very important role in the process as active participants, they are not only objects but subjects inside the open innovation ecosystem. Common development work includes activities such as creation, development, validation and testing. [5], [6], [7]

The Mental Health Living Lab is an environment where rehabilitees, workers, students and lecturers are working together as equal partners. The main purpose of the process is to develop mental health services together with rehabilitees and their families so that users are the main actors in designing new practices and services. The Mental Health Living Lab combines research and innovation processes to user-centered and user-driven development work. It is important to involve rehabilitees strongly in action and decision-making processes.

The students of Degree Programmes of Nursing and Social Services have taken part in Living Lab development work. First teams were working in family work, day activities, marketing and communication tasks. The development work included activities that supported mental health wellbeing, group activities and creative activities.

In spring 2016, there was a seminar where participants introduced the main actions that were provided during the academic year 2015-2016 for Mental Health Living Lab. The students were involved in planning the seminar together with rehabilitees. In addition to presentations of activities there were for example common poster and art exhibitions, a panel discussion, music activities and art workshops during the seminar.

\section{METHODOLOGY}

The data was collected in a feedback survey. The survey consisted of both qualitative and quantitative questions. Four of the questions were open-ended questions. Two of the questions were based on the Likert scale with five options, where number one marked "strongly disagree" and number five "strongly agree". The quantitative data was processed by using SPSS statistics and open questions were categorized by content analysis. The number of returned feedback forms was $\mathrm{N}=58$.

Qualitative questions measured students' opinions on how they see the living lab environment as a part of their studies, what kind of competences and knowledge the seminar and the preparing work of the seminar developed and how the seminar supported their multi-professional working skills. The purpose of quantitative questions was to measure the students' opinions on how useful the learning experience in the living lab was and how important the multi-professional co-operation was during the studies.

\section{RESULTS}

According to the feedback, multi-professional learning in Living Lab offered students an opportunity to gather theory and practice together and explore it in an authentic environment. There were both positive and negative comments concerning project learning in Living Lab environment. The students strongly agreed or agreed $(94,8 \%)$ on the importance of multi-professional collaboration. The average of the question was 4.67 .

Table 1. Multi-professional collaboration is important at this stage of the studies.

\begin{tabular}{|c|c|c|}
\hline & Frequency & Percent \\
\hline Strongly disagree (1) & 0 & 0 \\
\hline Disagree (2) & 0 & 0 \\
\hline Neither agree nor disagree (3) & 3 & 5,2 \\
\hline Agree (4) & 13 & 22,4 \\
\hline Strongly agree (5) & 42 & 72,4 \\
\hline Total & 58 & 100,0 \\
\hline
\end{tabular}


Common benefits were connected to learning in Living lab and co-operation with real working life partners. Students reported Living Lab as an interesting and educational way to improve professional skills. This learning method was seen refreshing compared to traditional lessons. One important issue was that working together with rehabilitees helped students to decrease stigma and prejudices towards mental health problems. They also felt that they developed their teamwork and negotiation skills. It was a natural way to search knowledge and deepen it with another profession. Benchmarking among other profession gave lots of new perspectives and ways of thinking in the field of health care.

"The significance of multi-professional learning cannot be emphasize too much".

"During the studies it is very important to practice multi-professional working".

"We should have even more multi-professional learning during studies".

The main challenge was the workload during this project. Students had several other courses at the same time and they felt that they did not have enough time to do all the tasks required and to cooperate with students of other fields. The project work and collaboration with other groups caused problems as students were not familiar with other groups' work while being busy with own group's tasks. Students also hoped to hear even more stories of rehabilitees while working with them. From the lecturers' side there were challenges in supervising students and organising the project.

"There was too much to do in addition to other studies".

"There was a lot of work compared to the credits of the study unit".

"The project work of other groups remained distant".

"There should have been more concrete co-operation with nursing students."

However, most of the students $(87,9 \%)$ strongly agreed or agreed that the learning experience of the project was useful. The average of the students' answers was 4.17 .

Table 2. The learning experience of the project is useful.

\begin{tabular}{|c|c|c|}
\hline & Frequency & Percent \\
\hline Strongly disagree (1) & 1 & 1,7 \\
\hline Disagree (2) & 1 & 1,7 \\
\hline Neither agree nor disagree (3) & 5 & 8,6 \\
\hline Agree (4) & 31 & 53,4 \\
\hline Strongly agree (5) & 20 & 34,5 \\
\hline Total & 58 & 100,0 \\
\hline
\end{tabular}

At the end of the project there was a seminar where rehabilitees and students together presented their project outputs. Students arranged mental health poster presentations and workshops where they participated in the activities with the rehabilitees. The seminar was appreciated by many. Different activities improved the students' counselling skills and during this project the students felt that they gained more professional self-confidence to work with clients in the future.

"The seminar day was really nice".

"The seminar challenged to think new ways on how to interact and work with a person who has mental health problems".

"It seemed that the rehabilitees liked the seminar day and found it very interesting".

\section{CONCLUSIONS}

During the Mental Health Living Lab project students developed a lot of professional knowledge of mental health problems, mental health care and skills to promote mental health. Studying in Living Lab 
improved students' professional and co-operational skills as well as time management skills extensively. The results show that students achieved a learning experience of empowerment and innovative collaboration with other professions.

Students were able to integrate into practical development work in Mental Health Living Lab and had an opportunity to work as equal partners with the rehabilitees. The results confirm the value of multiprofessional learning in a Living Lab environment. In this project, learning experiences and challenges were mostly the same as in the writers' previous project [8]. In the future, the purpose of reflecting and evaluating learning processes during the project has to be emphasised more to further improve the metacognitive skills.

\section{REFERENCES}

[1] K. Isoherranen. Uhka vai mahdollisuus - moniammatillista yhteistyötä kehittämässä, Doctoral Dissertation. University of Helsinki, 2012.

[2] P. Virtanen, M. Suoheimo, S. Lamminmäki, P. Ahonen and M. Suokas. Matkaopas asiakaslähtöisten sosiaali- ja terveyspalvelujen kehittämiseen. Tekesin katsaus 281/2011

[3] K. Collin, UM. Valleala, S. Herranen, S. Paloniemi and P. Pyhälä-Liljeström, Forms and challenges of interprofessional collaboration in the treatment process of medical emergency work. Sosiaalilääketieteellinen aikakauslehti - Journal of Social Medicine. 49. pp.31-43, 2012.

[4] U. Hylin, Interprofessional education. Aspects on learning together on an interprofessional training ward. Dissertation. Karolinska Institutet, Department of clinical science and education. Södersjukhuset, 2010.

[5] A. Ståhlbröst and M. Holst, The Living Lab Methodology Handbook. A Transnational Nordic Smart City Living Lab Pilot - SmartIES, 2012.

[6] S. Leminen, Living Labs as Open Innovation Networks. Networks, Roles and Innovation Outcomes. Doctoral dissertations. Aalto University. Department of Industrial Engineering and Management, 2015.

[7] S. Heikkanen and M. Österberg (eds.), Living Lab ammattikorkeakoulussa. Ammattikorkeakoulujen neloskierre - hanke, Haaga-Helia ammattikorkeakoulu, 2012.

[8] C. Saarikivi, A. Eskelinen and M. Bergman, "Students' experiences of multi-professional collaboration in a mental health and substance abuse development project", ICERI 2015 Proceedings, 8th International Conference of Education, Research and Innovation, Seville/Spain: IATED, 2015. 